\title{
An assessment of green export opportunities for Barbados
}

\author{
Winston Moore
}

ABSTRACT

\begin{abstract}
Transitioning towards a green economy -one that focuses on reducing environmental risks and resource scarcities, while also improving well-being - has been put forward as one possible path towards sustainable development. While the potential advantages of pursuing a green development path are clear, moving forward on the green agenda requires guaranteed support for emerging businesses and industries. Consequently, the policy agenda will have to be tailored to these new green business areas. This study assesses various green businesses and their potential suitability for the small island State of Barbados.
\end{abstract} services, Barbados 


\section{Introduction}

With a fixed exchange rate, Barbados depends on its foreign exchange earnings from the export of goods and services to finance its imports. These imports are used in virtually every aspect of production, from tourism to manufacturing. In 2010 total merchandise exports amounted to US\$ 429 million, equivalent to less than $1 \%$ of total world exports. As table 1 shows, these exports were concentrated in a few key areas, mainly agricultural products and manufactures. Most of the country's exports go to the United States (25\%) and the European Union (20.4\%). Meanwhile, total exports of services in 2010 came to US\$ 1.6 billion, representing about $0.04 \%$ of total world exports. These trade patterns reflect not only geographical factors (such as the proximity of the United States), but also historical precedent (for example, the export of sugar to Europe under preferential trading arrangements). Travel accounted for the bulk of these export receipts (67\%), with other commercial services making up most of the remainder.

Given the relatively high concentration of the island's exports (both goods and services) in a few key areas, the export of green goods and services could provide opportunities for diversification into higher value added areas. Indeed, in 2011 Prime Minister Freundel Stuart $^{1}$ noted that one of the development objectives for the island over the medium to long term would be to become "the most environmentally advanced, green country in Latin America and the Caribbean". In pursuit of this objective the island completed a Green Economy Scoping Study (Moore and others, 2012), assessing the potential opportunities for pursuing a green growth strategy. One of the recommendations of the study was that an assessment of the trade in environmental goods and services in Barbados should be carried out in order for the island to fully harness the potential of the green economy.

1 Address given at the launch of the Government of Barbados and United Nations Environment Programme (UNEP) Partnership for a Resource-Efficient Green Economy in Barbados, held at the Faculty of Medical Sciences, University of the West Indies.

TABLE 1

Barbados: main imports and exports, 2010

(United States dollars)

\begin{tabular}{lr}
\hline Goods & Trade value \\
\hline Imports & 484333718 \\
Mineral fuels, mineral oils and products of their distillation & 146735448 \\
Machinery and mechanical appliances; parts thereof & 110024097 \\
Electrical machinery and equipment and parts thereof; sound recorders and reproducers, television image and sound & \\
recorders and reproducers, and parts and accessories of such articles & 73323026 \\
Vehicles other than railway or tramway rolling stock & 64181655 \\
Pharmaceutical products & 896805458 \\
Other commodities & 202756058 \\
Exports & 72023763 \\
Mineral fuels, mineral oils and products of their distillation & 45661270 \\
Pharmaceutical products & 17622731 \\
Beverages, spirits and vinegar & 12702310 \\
Optical, photographic, cinematographic, measuring, checking, precision, medical or surgical instruments and apparatus; \\
clocks and watches; musical instruments; parts and accessories thereof \\
Animal or vegetable fats and oils & 157680270 \\
Other commodities & \\
\hline
\end{tabular}

Source: World Trade Organization (wTo), Report by the Chairman, Ambassador Manuel A.J. Teehankee, to the Trade Negotiations Committee, Geneva, Committee on Trade and Environment, 2011. 
This paper therefore attempts to identify potential green export opportunities for Barbados, assessing both goods and services. For goods, the World Trade Organization (WTO) draft list of the universe of environmental goods (WTO, 2011) is employed to identify areas where the island has comparative advantages and, for services, an assessment is undertaken of how well potential green business opportunities match the business environment in Barbados. The results of the study could be used as an input for the development of industrial, fiscal and trade policies. In relation to trade policy, this exercise could be used a case study of the potential implications of accepting the wTO draft list of the universe of environmental goods. Where potential comparative advantages are identified, policymakers could spur growth in these areas through incentives $^{2}$ and with the support of an appropriate industrial policy framework.

2 This could be done through education and training, access to credit for entrepreneurs, mentoring and access to trade shows. Many of these incentives are already available in Barbados, but are not specifically targeted at green goods.
The most similar studies found in the existing literature on the topic are those by Huberty and Zachman (2011) and Ernst and Young (2008). Unlike Huberty and Zachman (2011), however, the present study does not attempt to identify green goods, but uses the wTO draft list of environmental goods to identify potential comparative advantages. This analysis could be relevant to trade negotiators examining the potential impact of accepting this list on trade in Barbados (and, to some extent, the Caribbean as a whole). The paper also differs from both Huberty and Zachman (2011) and Ernst and Young (2008) because it considers potential opportunities in both merchandise trade and services.

The remainder of this paper is structured as follows. After the introduction, section II discusses the concept of green goods and services and attempts to show the relationship between the various definitions currently being employed. Section III outlines the methodological approach used in this study to assess potential green export opportunities and section IV presents the results. Section $\mathrm{V}$ summarizes the main findings and puts forward some recommendations for future policy changes.

\section{II}

\section{Identification of green goods and services}

The terms "green goods and services" and "environmental goods and services" are used interchangeably in the relevant literature. The Organisation for Economic Cooperation and Development (OECD/EUROSTAT, 1999) identifies the environmental goods and services industry as one that is largely made up of activities that produce goods and services to measure, prevent, limit, minimize or correct environmental damage to water, air and soil, as well as problems relating to waste, noise and ecosystems. The definition categorizes goods and services according to whether they involve pollution management, cleaner technologies and products or resource management. In each of those categories, activities are further classified into three subgroups: (i) production of equipment and specific materials; (ii) provision of services, and (iii) construction and installation of facilities (see figure 1).

The definition of the environmental goods and services industry is, however, still somewhat contentious and, according to Sinclair-Desgagné (2008), it encroaches on other better-known industrial classifications. For example, rather than including solar cells, windmills and ethanol in the energy sector and ecotourism as a subcategory of tourism, they would be classified under the environmental goods and services industry. The distinction between environmental and non-environmental goods and services is also somewhat ambiguous. For example, it is not clear if all resource-efficient technological and managerial enhancements should result in an environmental goods and services classification.

Building on this early work, the Bureau of Labor Statistics of the United States Department of Labor uses a similar definition to that developed by OECD/EUROSTAT (1999), identifying green businesses as those that are engaged in the production or provision of services that enhance the environment or conserve natural resources (Bureau of Labor Statistics, 2012). However, it seeks to address some of the criticisms levelled at OECD/ EUROSTAT (1999) by providing clear guidance in relation to environmental services companies and natural resources conservation. Figure 2 presents the various green goods categories identified by the Bureau of Labor Statistics along with their subcategories. 
FIGURE 1

\section{Organisation for Economic Cooperation and Development and Statistical Office of the European Communities: categories of environmental goods and services}
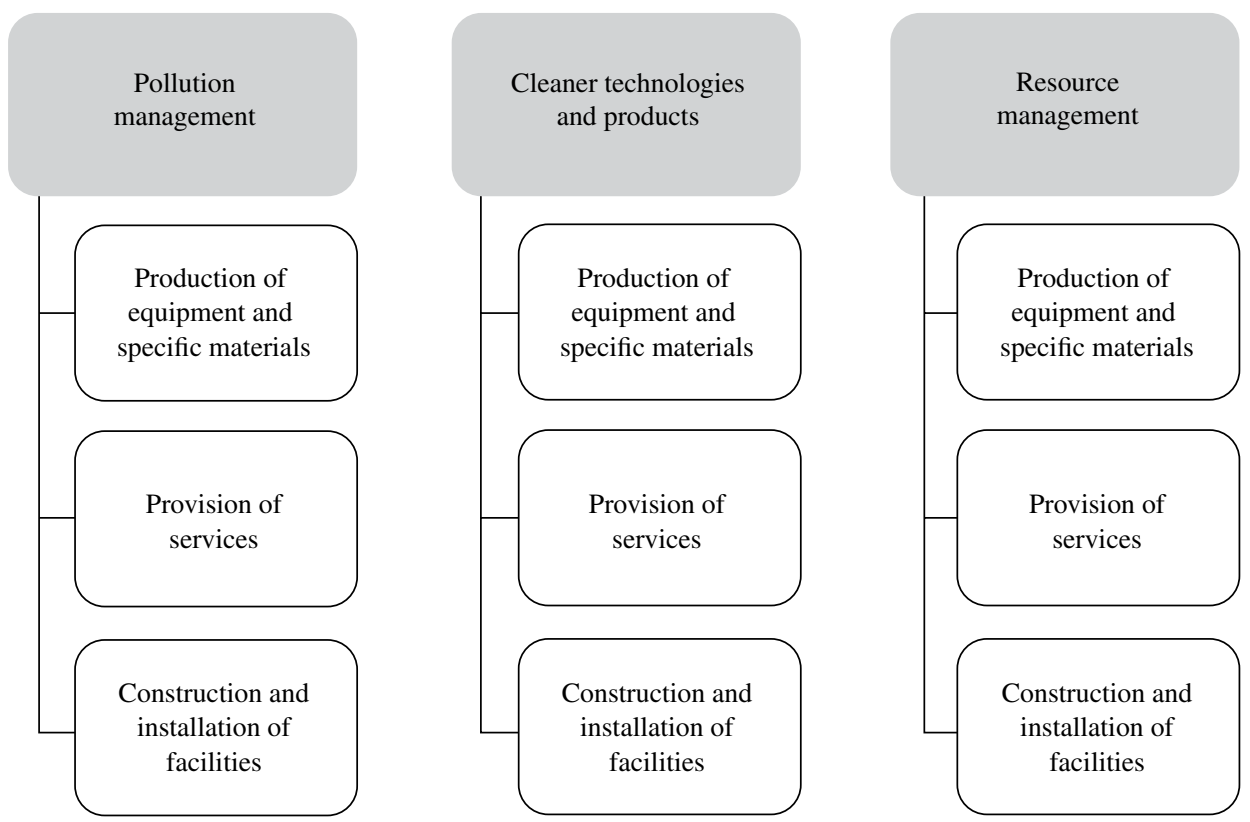

Source: Organisation for Economic Cooperation and Development/Statistical Office of the European Communities (OECD/EUROSTAT), The Environmental Goods and Services Industry: Manual for Data Collection and Analysis, Paris, oECD Publishing, 1999.

FIGURE 2

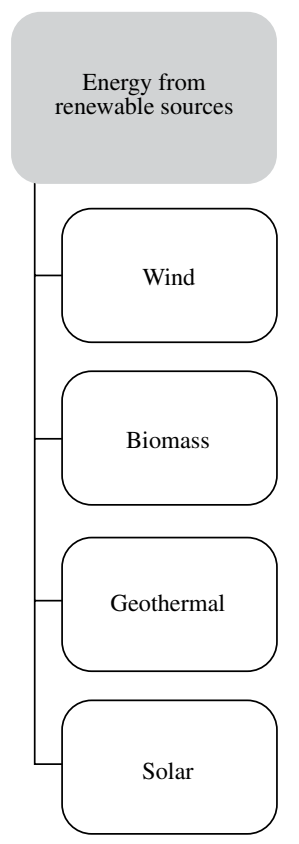

Bureau of Labor Statistics: categories of green goods and services
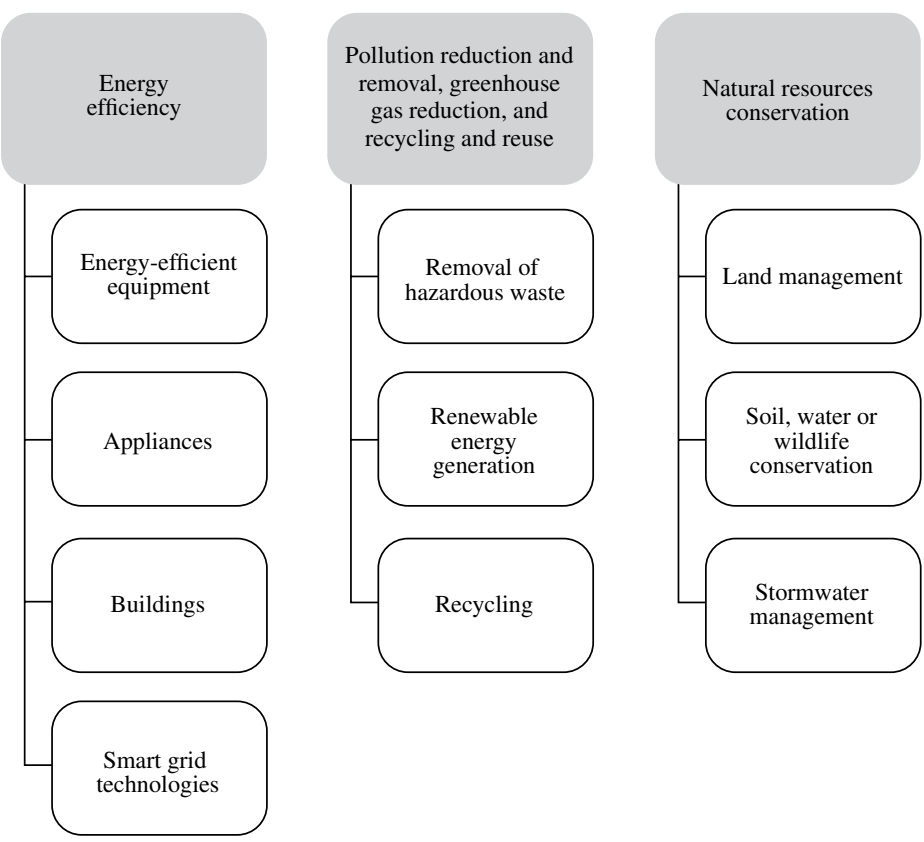

Environmental compliance, education and training, and public awareness

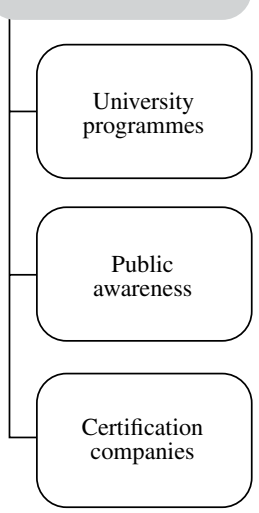

Source: Bureau of Labor Statistics, "Green Goods and Services”, Department of Labor of the United States, 2012 [online] http://www.bls.gov/ ggs/ggsoverview.htm. 
The Bureau of Labor Statistics distinguishes green goods and services from other similar goods or services by their use of either federal standards (for example, organic certification by the United States Department of Agriculture or the Energy Star programme run by the United States Environmental Protection Agency) or widely used industry standards (such as the Leadership in Energy and Environmental Design (LEED) programme). While the use of these industry and national standards addresses the criticism of the relatively arbitrary classification scheme used by OECD/EUROSTAT (1999), the approach still fails to resolve the underlying threshold question: at what point is a business or a good considered green?

Rather than a adopting a broad definition of green goods and services, the Republic of Korea has focused its Green New Deal ${ }^{3}$ on 27 core high-technology areas.

3 The Green New Deal in the Republic of Korea is a stimulus plan introduced in 2009 in response to the recession, to stimulate growth
The plan aims to build a resource-efficient economy with an enhanced long-term potential output. Each investment is ranked according to its associated time frame: (i) short-term gradual; (ii) medium-term intensive; and (iii) long-term intensive (see figure 3). Figure 3 shows the main export categories, the type of goods and services targeted and the nature of the investment depending on whether it relates to a short-, medium- or long-term objective. While the selection of industries identified for support under the Korean Green New Deal seems somewhat limited, it sends a clear message to the private sector on the areas where there is likely to be current and future government support; and although these 27 core areas were not developed for the purposes of measurement, they leave no doubt as to the sectors that the government considers green.

in the short run and reorient the economy in the medium to long term towards more resource-efficient areas.

Republic of Korea: categories of green goods and services

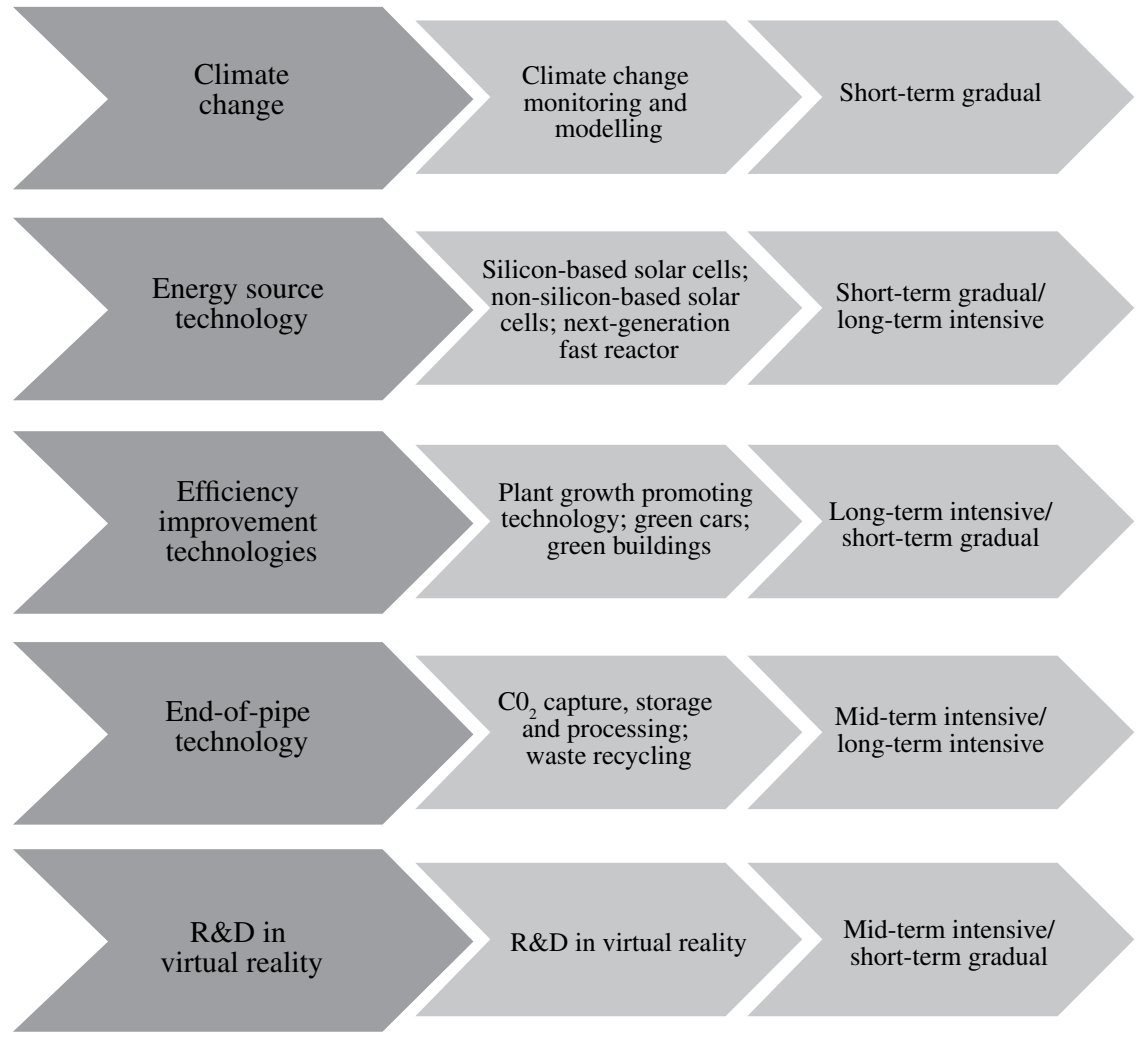

Source: World Bank, "Lessons from the Implementation of Republic of Korea's Green Stimulus”, INFRA Update, 2010 [online] http://siteresources. worldbank.org/INTSDNET/Resources/5944695-1247775731647/INFRA_Korea_Newsletter.pdf.

$\mathrm{R} \& \mathrm{D}=$ research and development. 
An alternative definition of the concept of green goods can be obtained from the international trade arena. The central objective of the Doha Development Agenda launched at the fourth World Trade Organization (WTO) Ministerial Conference is to enhance support for trade and environmental policies. At present, negotiations are taking place in three main areas:

(i) The relationship between wTO rules and multilateral environmental agreements;

(ii) The collaboration between wTO and secretariats of those multilateral environmental agreements;

(iii) The elimination of tariffs and non-tariff barriers on environmental goods and services.

In relation to the third area, wTO members are currently holding negotiations on the identification of environmental goods, but have not yet addressed the definition of services. A number of proposals have been put forward in relation to goods: one calls for the use of broad criteria as the basis for their identification; another suggests introducing a request-and-offer process, with members proposing the items to be included and for which they are prepared to assume liberalization commitments. Under a third proposal two lists would be prepared, one for developed countries and another for developing countries, drawn from a single universe of goods; or alternatively, a common list could be prepared for all members and a second list would comprise only those products specifically selected by developing countries for exemption or a lower level of tariff treatment. Figure 4 contains an aggregated version of the proposed reference universe of environmental goods and services.

The reference universe is based on the 2002 revision of the Harmonized Commodity Description and Coding System (HS2002) classification at the six-digit level and is available in wTO (2011). A sample core list of goods has been proposed as the starting point for discussion (see table 2).

Without international agreement, these green goods and services will continue to be subject to the same tariff and non-tariff barriers to trade as other less resource-efficient goods and services. Nevertheless, the Green Economy Scoping Study (Moore and others, 2012) for Barbados notes that, given the environmental constraints faced by the island and the demand for decent employment opportunities, a green growth strategy would have significant potential as a means of generating sustainable growth and development. The next section therefore identifies a potential approach to ranking the various green export opportunities that policymakers should consider for future policy support.
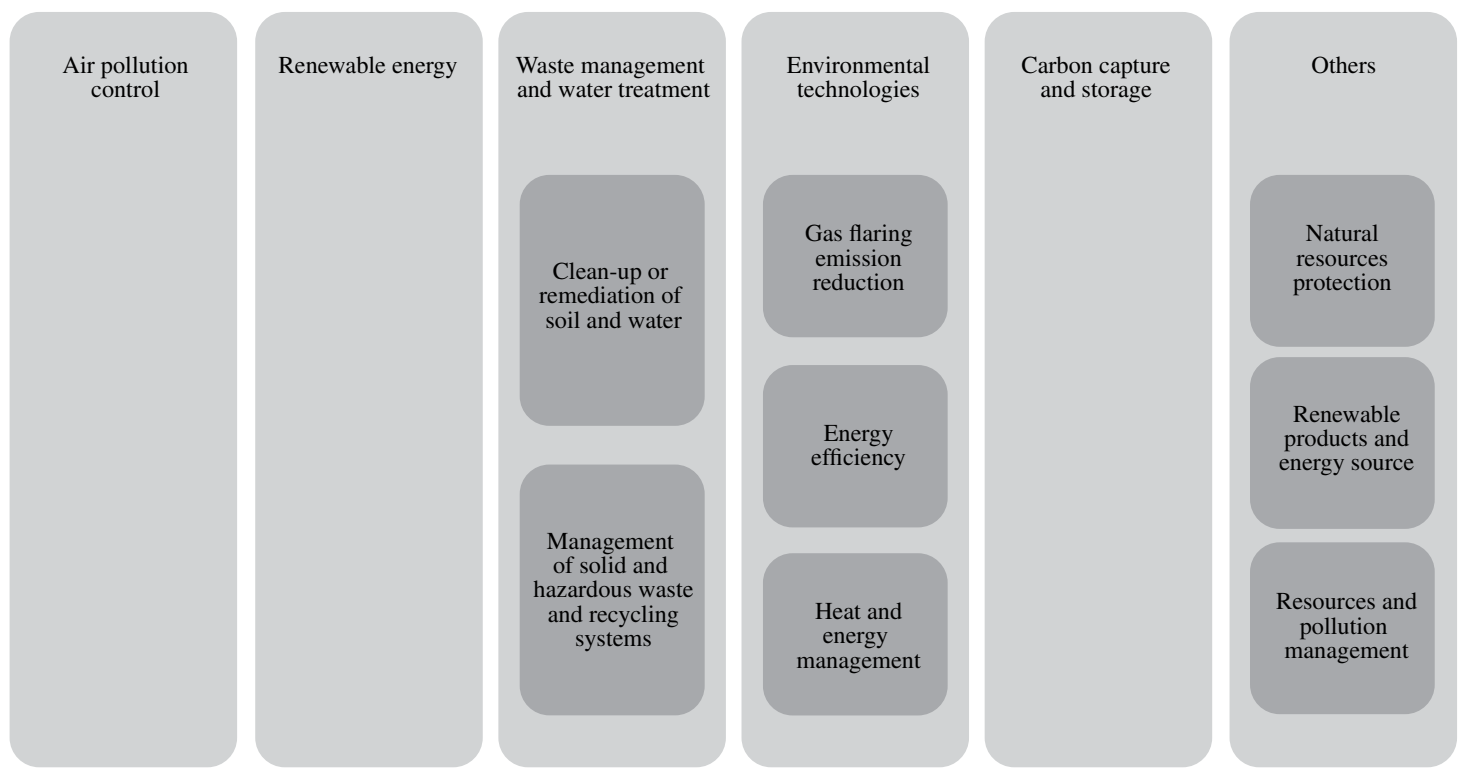

Source: World Trade Organization (wTO) (2011), Report by the Chairman, Ambassador Manuel A.J. Teehankee, to the Trade Negotiations Committee, Geneva, Committee on Trade and Environment, 2011. 


\section{Sample core list of environmental goods}

\begin{tabular}{|c|c|c|}
\hline HS2002 code & Description & Category and subcategory \\
\hline 4601 & $\begin{array}{l}\text { Plaits and similar products of plaiting materials, whether } \\
\text { or not assembled into strips; plaiting materials, plaits and } \\
\text { similar products of plaiting materials, bound together in } \\
\text { parallel strands or woven, in sheet form, whether or not } \\
\text { being finished articles }\end{array}$ & \\
\hline 460120 & - Mats, matting and screens of vegetable materials & $\begin{array}{l}\text { Waste management and water treatment: } \\
\text { - Waste management, recycling and remediation }\end{array}$ \\
\hline 7308 & $\begin{array}{l}\text { Structures (excluding prefabricated buildings of heading } \\
\text { 94.06) and parts of structures (for example, bridges and } \\
\text { bridge sections, lock gates, towers, lattice masts, roofs, } \\
\text { roofing frameworks, doors and windows and their frames } \\
\text { and thresholds for doors, shutters, balustrades, pillars and } \\
\text { columns), of iron or steel; plates, rods, angles, shapes, } \\
\text { sections, tubes and the like, prepared for use in structures, } \\
\text { of iron or steel }\end{array}$ & \\
\hline 730820 & - Towers and lattice masts & $\begin{array}{l}\text { Renewable energy } \\
\text { Other: } \\
\text { - Renewable products and energy source }\end{array}$ \\
\hline 7321 & $\begin{array}{l}\text { Stoves, ranges, grates, cookers (including those with } \\
\text { subsidiary boilers for central heating), barbecues, braziers, } \\
\text { gas-rings, plate warmers and similar non-electric domestic } \\
\text { appliances, and parts thereof, of iron or steel }\end{array}$ & \\
\hline 732111 & $\begin{array}{l}\text { - Cooking appliances and plate warmers: for gas fuel } \\
\text { or for both gas and other fuels }\end{array}$ & $\begin{array}{l}\text { Environmental technologies: } \\
\text { - Cleaner or more resource-efficient technologies } \\
\text { and products }\end{array}$ \\
\hline 7324 & Sanitary ware and parts thereof, of iron or steel & \\
\hline 732490 & - Other, including parts & $\begin{array}{l}\text { Waste management and water treatment: } \\
\text { - Waste water management and potable water treatment } \\
\text { Carbon capture and storage } \\
\text { Environmental technologies: } \\
\text { - Efficient consumption of energy technologies }\end{array}$ \\
\hline 8402 & $\begin{array}{l}\text { Steam or other vapour generating boilers (other than central } \\
\text { heating hot water boilers capable also of producing low } \\
\text { pressure steam); super-heated water boilers }\end{array}$ & \\
\hline 840290 & - Parts & $\begin{array}{l}\text { Carbon capture and storage } \\
\text { Environmental technologies: } \\
\text { - Efficient consumption of energy technologies } \\
\text { Waste management and water treatment: } \\
\text { - Management of solid and hazardous waste } \\
\text { and recycling systems } \\
\text { - Waste management, recycling and remediation }\end{array}$ \\
\hline 8404 & $\begin{array}{l}\text { Auxiliary plant for use with boilers of heading } 84.02 \text { or } \\
84.03 \text { (for example, economisers, super-heaters, soot } \\
\text { removers, gas recoverers); condensers for steam or other } \\
\text { vapour power units }\end{array}$ & \\
\hline 840410 & - Auxiliary plant for use with boilers of 84.02 or 84.03 & $\begin{array}{l}\text { Waste management and water treatment: } \\
\text { - Waste management, recycling and remediation } \\
\text { - Management of solid and hazardous waste } \\
\text { and recycling systems } \\
\text { Carbon capture and storage } \\
\text { Environmental technologies: } \\
\text { - Efficient consumption of energy technologies }\end{array}$ \\
\hline 8405 & $\begin{array}{l}\text { Producer gas or water gas generators, with or without their } \\
\text { purifiers; acetylene gas generators and similar water process } \\
\text { gas generators, with or without their purifiers }\end{array}$ & \\
\hline
\end{tabular}


Table 2 (continued)

\begin{tabular}{|c|c|c|}
\hline HS2002 code & Description & Category and subcategory \\
\hline 840510 & $\begin{array}{l}\text { - Producer gas or water gas generators, with or without } \\
\text { their purifiers; acetylene gas generators and similar water } \\
\text { process gas generators, with or without their purifiers }\end{array}$ & $\begin{array}{l}\text { Air pollution control } \\
\text { Renewable energy } \\
\text { Waste management and water treatment: } \\
\text { - Waste water management and potable water treatment } \\
\text { Carbon capture and storage } \\
\text { Environmental technologies: } \\
\text { - Efficient consumption of energy technologies }\end{array}$ \\
\hline 8406 & Steam turbines and other vapour turbines & \\
\hline 840681 & $\begin{array}{l}\text { - Turbines for marine propulsion: of an output } \\
\text { exceeding } 40 \mathrm{MW}\end{array}$ & Renewable energy \\
\hline 8409 & $\begin{array}{l}\text { Parts suitable for use solely or principally with the engines } \\
\text { of heading } 84.07 \text { or } 84.08\end{array}$ & \\
\hline 840999 & - Other: other & $\begin{array}{l}\text { Air pollution control } \\
\text { Environmental technologies: } \\
\text { - Efficient consumption of energy technologies } \\
\text { - Noise and vibration abatement } \\
\text { Carbon capture and storage }\end{array}$ \\
\hline 8410 & Hydraulic turbines, water wheels, and regulators therefor & \\
\hline 841011 & $\begin{array}{l}\text { - Hydraulic turbines and water wheels of a power not } \\
\text { exceeding } 1000 \mathrm{~kW}\end{array}$ & $\begin{array}{l}\text { Renewable energy } \\
\text { Environmental technologies: } \\
\text { - Efficient consumption of energy technologies } \\
\text { Carbon capture and storage }\end{array}$ \\
\hline 841012 & $\begin{array}{l}\text { - Hydraulic turbines and water wheels, power } \\
1000-10000 \mathrm{~kW}\end{array}$ & $\begin{array}{l}\text { Environmental technologies: } \\
\text { - Efficient consumption of energy technologies } \\
\text { Carbon capture and storage }\end{array}$ \\
\hline 841090 & $\begin{array}{l}\text { - Hydraulic turbines, water wheels, and regulators; } \\
\text { parts, including regulators }\end{array}$ & $\begin{array}{l}\text { Renewable energy } \\
\text { Environmental technologies: } \\
\text { - Efficient consumption of energy technologies } \\
\text { Carbon capture and storage }\end{array}$ \\
\hline 8411 & Turbo-jets, turbo-propellers and other gas turbines & \\
\hline 841181 & - Other gas turbines of a power not exceeding $5000 \mathrm{~kW}$ & $\begin{array}{l}\text { Renewable energy } \\
\text { Environmental technologies: } \\
\text { - Efficient consumption of energy technologies } \\
\text { Carbon capture and storage } \\
\text { Others: } \\
\text { - Environmentally preferable products based on end-use } \\
\text { or disposal characteristics }\end{array}$ \\
\hline 841182 & - Other gas turbines of a power exceeding $5000 \mathrm{~kW}$ & $\begin{array}{l}\text { Renewable energy } \\
\text { Environmental technologies: } \\
\text { - Efficient consumption of energy technologies } \\
\text { Carbon capture and storage } \\
\text { Others: } \\
\text { - Environmentally preferable products based on end-use } \\
\text { or disposal characteristics }\end{array}$ \\
\hline 8418 & $\begin{array}{l}\text { Refrigerators, freezers and other refrigerating or freezing } \\
\text { equipment, electric or other; heat pumps other than air } \\
\text { conditioning machines of heading } 84.15\end{array}$ & \\
\hline 841861 & $\begin{array}{l}\text { - Other refrigerating or freezing equipment; heat pumps: } \\
\text { compression-type units whose condensers are heat } \\
\text { exchangers }\end{array}$ & Renewable energy \\
\hline 8419 & $\begin{array}{l}\text { Machinery, plant or laboratory equipment, whether or not } \\
\text { electrically heated (excluding furnaces, ovens and other } \\
\text { equipment of heading } 85.14 \text { ), for the treatment of materials } \\
\text { by a process involving a change of temperature such as } \\
\text { heating, cooking, roasting }\end{array}$ & \\
\hline 841919 & $\begin{array}{l}\text { - Instantaneous or storage water heaters, } \\
\text { non-electric: other }\end{array}$ & Renewable energy \\
\hline
\end{tabular}


Table 2 (continued)

\begin{tabular}{|c|c|c|}
\hline HS2002 code & Description & Category and subcategory \\
\hline 841950 & - Heat exchange units & $\begin{array}{l}\text { Renewable energy } \\
\text { Environmental technologies: } \\
\text { - Gas flaring emission reduction } \\
\text { - Efficient consumption of energy technologies } \\
\text { - Heat and energy management } \\
\text { Carbon capture and storage }\end{array}$ \\
\hline 8479 & $\begin{array}{l}\text { Machines and mechanical appliances having individual } \\
\text { functions, not specified or included elsewhere in } \\
\text { this chapter }\end{array}$ & \\
\hline 847989 & - Other machines and mechanical appliances: other & $\begin{array}{l}\text { Air pollution control } \\
\text { Waste management and water treatment: } \\
\text { - Management of solid and hazardous waste } \\
\text { and recycling systems } \\
\text { Renewable energy } \\
\text { Others: } \\
\text { - Renewable products and energy source }\end{array}$ \\
\hline 8502 & Electric generating sets and rotary converters & \\
\hline 850231 & - Other generating sets: wind-powered & $\begin{array}{l}\text { Renewable energy } \\
\text { Others: } \\
\text { - Renewable products and energy source }\end{array}$ \\
\hline 8504 & $\begin{array}{l}\text { Electrical transformers, static converters (for example, } \\
\text { rectifiers) and inductors }\end{array}$ & \\
\hline 850410 & - Ballasts for discharge lamps or tubes & $\begin{array}{l}\text { Environmental technologies: } \\
\text { - Efficient consumption of energy technologies } \\
\text { Carbon capture and storage }\end{array}$ \\
\hline 8537 & $\begin{array}{l}\text { Boards, panels, consoles, desks, cabinets and other bases, } \\
\text { equipped with two or more apparatus of heading } 85.35 \text { or } \\
85.36 \text {, for electric control or the distribution of electricity, } \\
\text { including those incorporating instruments or apparatus of } \\
\text { Chapter } 90 \text {, and numerical control apparatus, other than } \\
\text { switching apparatus of heading } 85.17\end{array}$ & \\
\hline 853710 & - For a voltage not exceeding $1000 \mathrm{~V}$ & Renewable energy \\
\hline 8541 & $\begin{array}{l}\text { Diodes, transistors and similar semiconductor devices; } \\
\text { photosensitive semiconductor devices, including } \\
\text { photovoltaic cells whether or not assembled in modules } \\
\text { or made up into panels; light emitting diodes; mounted } \\
\text { piezo-electric crystals }\end{array}$ & \\
\hline 854140 & $\begin{array}{l}\text { - Photosensitive semiconductor devices, including } \\
\text { photovoltaic cells whether or not assembled in modules } \\
\text { or made up into panels; light emitting diodes }\end{array}$ & $\begin{array}{l}\text { Renewable energy } \\
\text { Others: } \\
\text { - Renewable products and energy source }\end{array}$ \\
\hline 9001 & $\begin{array}{l}\text { Optical fibres and optical fibre bundles; optical fibre } \\
\text { cables other than those of heading } 85.44 \text {; sheets and plates } \\
\text { of polarising material; lenses (including contact lenses), } \\
\text { prisms, mirrors and other optical elements, of any material, } \\
\text { unmounted, other than such elements of glass not } \\
\text { optically worked }\end{array}$ & \\
\hline 900190 & - Other & Renewable energy \\
\hline 9002 & $\begin{array}{l}\text { Lenses, prisms, mirrors and other optical elements, of any } \\
\text { material, mounted, being parts of or fittings for instruments } \\
\text { or apparatus, other than such elements of glass not optically } \\
\text { worked }\end{array}$ & \\
\hline 900290 & - Other & Renewable energy \\
\hline 9027 & $\begin{array}{l}\text { Instruments and apparatus for physical or chemical analysis } \\
\text { (for example, polarimeters, refractometers, spectrometers, } \\
\text { gas or smoke analysis apparatus); instruments and apparatus } \\
\text { for measuring or checking viscosity, porosity, expansion, } \\
\text { surface tension or the like; instruments and apparatus for } \\
\text { measuring or checking quantities of heat, sound or light } \\
\text { (including exposure meters); microtomes }\end{array}$ & \\
\hline
\end{tabular}


Table 2 (concluded)

\begin{tabular}{cll}
\hline HS2002 code & Description & Category and subcategory \\
\hline 902730 & $\begin{array}{l}\text { - Spectrometers, spectrophotometers and spectrographs } \\
\text { using optical radiations (UV, visible, IR) }\end{array}$ & $\begin{array}{l}\text { Environmental technologies: } \\
\text { - Environmental monitoring, analysis and assessment } \\
\text { equipment }\end{array}$ \\
9032 & $\begin{array}{l}\text { Automatic regulating or controlling instruments } \\
\text { and apparatus }\end{array}$ & \\
903210 & - Thermostats & $\begin{array}{l}\text { Environmental technologies: } \\
\text { - Environmental monitoring, analysis and assessment } \\
\text { equipment }\end{array}$ \\
& & $\begin{array}{l}\text { - Gas flaring emission reduction } \\
\text { - Efficient consumption of energy technologies } \\
\text { Carbon capture and storage }\end{array}$ \\
\hline
\end{tabular}

Source: World Trade Organization (wTo) (2011), Report by the Chairman, Ambassador Manuel A.J. Teehankee, to the Trade Negotiations Committee, Geneva, Committee on Trade and Environment, 2011.

HS: Harmonized Commodity Description and Coding System.

\section{III}

\section{Methodological approach}

As discussed in the previous section, the list of potential green goods and services is long and contentious. To avoid providing an arbitrary list of possible business areas or, even worse, an exhaustive list that is not necessarily relevant to the situation in Barbados, an analytical approach for evaluating business areas is employed. A schematic representation of that approach is presented in figure 5. The approach adopted must take into account a universe of green business opportunities and, given the focus of this paper on export opportunities, the list proposed in WTO (2011) is a good starting point. However, as that list excludes services - an area in which Barbados is likely to have a comparative advantage - the study also uses the Bureau of Labor Statistics (2012) lists to generate a comprehensive database of green businesses.

FIGURE 5

Schematic representation of green export opportunities

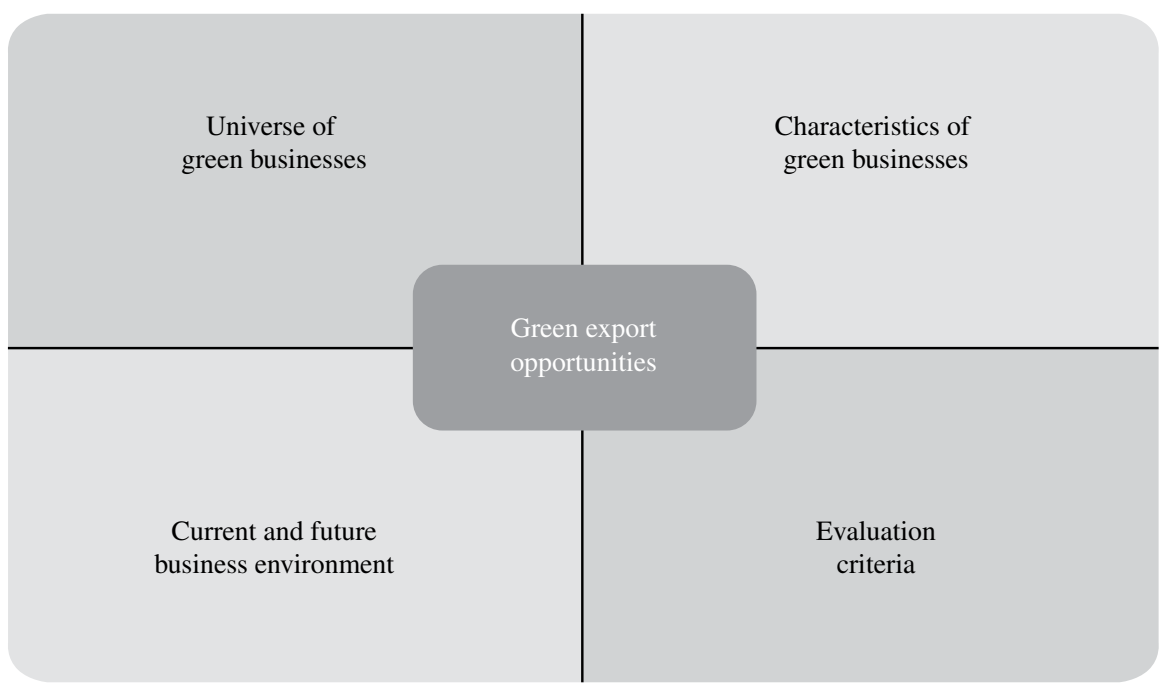

Source: prepared by the author. 
One means of identifying potential green business export opportunities is to calculate indices of revealed comparative advantage (Balassa, 1986 and 1989). These indices provide a simple measure of the extent to which a country or regional group is more specialized in a particular area of goods relative to another. The most popular comparative advantage index is the revealed export advantage (REA):

$$
R E A=\frac{X_{i j} / \sum_{j=1}^{J} X_{i j}}{\sum_{n=1}^{N} X_{n j} / \sum_{n=1}^{N} \sum_{j=1}^{J} X_{i j}}
$$

where $X_{i j}$ are the exports of good $j$ by country $i$ and $X_{n j}$ are the exports of the same good by country group $n$. The country is assumed to have a revealed comparative advantage if REA $>1$ and a revealed comparative disadvantage if REA $<1$.

Vollrath (1991) proposes three alternative indices: (i) relative trade advantage ( $R T A$ ); (ii) the logarithm of the relative export advantage ( $\ln R E A$ ), and (iii) revealed competitiveness $(R C)$. These three indices are calculated as follows:

$$
\begin{gathered}
R E A=\frac{X_{i j} / \sum_{j=1}^{J} X_{i j}}{\sum_{n=1}^{N} X_{n j} / \sum_{n=1}^{N} \sum_{j=1}^{J} X_{i j}} \\
\frac{M_{i j} / \sum_{j=1}^{J} M_{i j}}{\sum_{n=1}^{N} M_{n j} / \sum_{n=1}^{N} \sum_{j=1}^{J} M_{i j}} \\
\ln R E A=\ln \left(\begin{array}{c}
\sum_{i j}^{N} / \sum_{j=1}^{J} X_{n j} / \sum_{n=1}^{N} \sum_{j=1}^{J} X_{i j}
\end{array}\right)- \\
\operatorname{RC}\left(\frac{\ln \left(\begin{array}{c}
\sum_{i j}^{N} / \sum_{j=1}^{J} X_{i j} \\
\sum_{n=1}^{N} X_{n j} / \sum_{n=1}^{N} \sum_{j=1}^{J} X_{i j}
\end{array}\right)}{M_{n j} / \sum_{n=1}^{N} / \sum_{j=1}^{J} M_{i j}^{J}{ }_{j=1} M_{i j}}\right)
\end{gathered}
$$

For all three indices, positive values would indicate that the country has a revealed comparative advantage. It should be noted that all the indices outlined above can be distorted by government policies and other interventions. This caveat should be considered when interpreting the results. All values for commodity exports and imports are obtained from the United Nations Commodity Trade Statistics Database (COMTRADE) using the six-digit HS2002 classification and trade data for 2005-2010.4

Owing to the limited data available on international services, a similar analysis could not be carried out for service exports. Instead, a swOT (strengths, weaknesses,

4 The Harmonized System (HS2002) codes for the universe of green goods are: 250300, 271011, 271019, 271111, 271112, 271113, 271114, 271119, 271121, 271129, 281810, 281820, 28183, 290911, 290919, 290920, 290930, 290941, 290942, 290943, 290944, 290949, 290950, 290960, 291411, 291412, 291413, 291419, 291421, 291422, 291423, 291429, 291431, 291440, 291450, 291461, 291469, 291470, 382490, 390210, 390220, 390230, 390290, 390799, 390910, 390920, 390930, 390940, 390950, 391110, 391190, 391211, 391212, 391220, 391231, 391239, 391290, 392010, 401699, 450410, 460120, 470710, 470720, 470730, 470790, 530310, 530410, 530490, 560314, 560710, 560721, 560811, 560890, 630510, 691010, 701931, 730300, 730410, 730421, 730431, 730439, 730441, 730449, 730451, 730459, 730490, 730511, 730512, 730519, 730520, 730531, 730539, 730590, 730610, 730620, 730630, 730640, 730650, 730660, 730690, 730711, 730719, 730721, 730722, 730723, 730729, 730791, 730792, 730793, 730799, 730820, 730900, 731010, 731021, 731029, 731100, 732111, 732190, 732490, 732510, 732690, 761100, 761290, 761300, 840211, 840212, 840219, 840220, 840290, 840310, 840390, 840410, 840420, 840490, 840510, 840590, 840610, 840681, 840682, 840690, 840790, 840890, 840991, 840999, 841011, 841012, 841013, 841090, 841111, 841112, 841121, 841122, 841181, 841182, 841191, 841199, 841210, 841221, 841229, $841231,841239,841280,841290,841311,841319,841320,841330$, $841340,841350,841360,841370,841381,841382,841391,841392$, $841410,841430,841440,841459,841480,841490,841510,841581$, $841610,841620,841630,841690,841780,841790,841810,841821$, 841830, 841840, 841861, 841869, 841919, 841939, 841940, 841950, $841960,841989,841990,842010,842091,842099,842119,842121$, $842123,842129,842131,842139,842191,842199,842220,842290$, $842833,842940,846291,846596,846599,846694,847130,847160$, $847170,847410,847420,847431,847432,847439,847480,847490$, $847710,847720,847730,847740,847751,847759,847780,847790$, $847920,847982,847989,847990,848110,848120,848130,848140$, $848180,848190,848210,848220,848230,848240,848250,848280$, $848291,848299,848340,848360,850161,850162,850163,850164$, $850231,850239,850300,850410,850421,850422,850423,850431$, $850432,850433,850434,850440,850450,850490,850511,850519$, $850520,850530,850590,850610,850630,850640,850650,850660$, $850680,850690,850720,850740,850780,850790,850980,851140$, $851150,851180,851190,851410,851420,851430,851440,851490$, $851629,851711,851721,851730,851750,851840,852090,852190$, $852210,852390,852540,852691,852812,852821,852830,853661$, $853710,853949,854140,854389,854390,870210,870290,870321$, $870322,870323,870324,870331,870332,870333,870390,870410$, $870421,870422,870423,870431,870432,870490,870510,870520$, $870530,870540,870590,871110,871120,871130,871140,871150$, $890790,900190,900290,901510,901520,901530,901540,901580$, 901590, 902410, 902480, 902490, 902511, 902519, 902580, 902590, 902610, 902620, 902680, 902690, 902710, 902720, 902730, 902740, 902750, 902780, 902790, 902810, 902820, 902830, 902890, 903010, 903020, 903031, 903039, 903040, 903082, 903083, 903089, 903090, 903110, 903120, 903130, 903140, 903149, 903180, 903190, 903210 , $903220,903281,903289,903290,903300,940510,940520,940540$ and 950720 . 
opportunities, threats) analysis was undertaken to determine how well the green business characteristics match the current and projected future business environment. Thus, elements of the business environment, such as whether there is an adequately trained labour force and the situation regarding licences and permits, infrastructure and finance, reflect the constraints on new businesses that are likely to influence their viability. This aspect of the model is complicated somewhat by the fact that a particular characteristic might be a constraint in the current business environment, but if it were eliminated by future policy changes, it could ultimately incentivize businesses in this area.

Following the approach outlined by Porter (2000), simple evaluation criteria were developed to examine how well each potential green export area matches the local business environment. For each goods or services category a score of 1-11 was obtained by answering the following questions:

- Is some proprietary technology needed? (Yes=0, $\mathrm{No}=1$ )
- Does Barbados have access to distribution channels? (Yes=1, No=0)

- Does Barbados have access to raw materials and other inputs (e.g. labour)? (Yes=1, No=0)

- Are there cost advantages independent of scale? (Yes=1, No=0)

- Are there modest capital requirements for start-ups? (Yes=1, No=0)

- Do product or technological standards already exist? (Yes=1, No=0)

- Are there regulatory barriers that potential start-ups would encounter? ( $\mathrm{Yes}=0, \mathrm{No}=1$ )

- Are there likely to be diseconomies of scale in production? ( $\mathrm{Yes}=1, \mathrm{No}=0$ )

- Does government support exist? (Yes=1, No=0)

- Are there a small number of potential substitutes or competitors? ( $\mathrm{Yes}=1, \mathrm{No}=0)$

- Are there low exit barriers? (Yes $=1, \mathrm{No}=0$ )

The final score for each product group was the sum of the scores for each of these individual questions.

\section{IV}

\section{Ranking potential green export opportunities}

In order to assess the consistency of the revealed comparative advantage indices, pairwise correlation statistics between the four indicators were calculated. In general, the indicators are all positively correlated: if one comparative advantage index suggests that the country has an advantage for a particular good, the other indicators are also likely to provide a similar result. In addition to the positive relationship, all of the bivariate correlation statistics were greater than 0.7 , indicating a high level of consistency in the results.

Given the consistency of the results, only the revealed competitiveness ( $\mathrm{RC}$ ) indices are provided in table 3, averaged over the 2005-2010 period. The results suggest that Barbados holds a revealed competitiveness advantage in relation to 24 goods across various green goods categories (see table 3 ).

Indices of revealed comparative advantage for green goods

\begin{tabular}{lllc}
\hline HS2002 code & Good & Category and subcategory of green goods & $\begin{array}{c}\text { Revealed } \\
\text { competitiveness } \\
\text { index (RC) }\end{array}$ \\
\hline 847780 & - Other machinery & $\begin{array}{l}\text { Environmental technologies: } \\
\text { - Efficient consumption of energy technologies } \\
\text { Carbon capture and storage }\end{array}$ & 5.545 \\
\hline 470790 & - Other, including unsorted waste and scrap & $\begin{array}{l}\text { Renewable energy } \\
\text { Others: } \\
\text { - Renewable products and energy source }\end{array}$ & 4.802 \\
\hline 731029 & - Of a capacity of less than 50 litres: other & $\begin{array}{l}\text { Waste management and water treatment: } \\
\text { - Waste water management and potable water treatment }\end{array}$ & 3.429 \\
\hline 841960 & - Machinery for liquefying air or other gases & Air pollution control & 3.071 \\
\hline
\end{tabular}


Table 3 (concluded)

\begin{tabular}{|c|c|c|c|}
\hline HS2002 code & Good & Category and subcategory of green goods & $\begin{array}{c}\text { Revealed } \\
\text { competitiveness } \\
\text { index (RC) }\end{array}$ \\
\hline 847730 & - Blow moulding machines & $\begin{array}{l}\text { Environmental technologies: } \\
\text { - Efficient consumption of energy technologies } \\
\text { Carbon capture and storage }\end{array}$ & 2.857 \\
\hline 271129 & - Other in gaseous state & $\begin{array}{l}\text { Environmental technologies: } \\
\text { - Gas flaring emission reduction } \\
\text { - Efficient consumption of energy technologies } \\
\text { Carbon capture and storage }\end{array}$ & 2.515 \\
\hline 841919 & $\begin{array}{l}\text { - Instantaneous or storage water heaters, } \\
\text { non-electric: Other }\end{array}$ & Renewable energy & 2.458 \\
\hline 850660 & - Primary cells \& primary batteries, air-zinc & $\begin{array}{l}\text { Renewable energy } \\
\text { Others: } \\
\text { - Renewable products and energy source }\end{array}$ & 1.974 \\
\hline 840290 & - Parts & $\begin{array}{l}\text { Environmental technologies: } \\
\text { - Efficient consumption of energy technologies } \\
\text { Carbon capture and storage }\end{array}$ & 1.924 \\
\hline 841940 & - Distilling or rectifying plant & $\begin{array}{l}\text { Waste management and water treatment: } \\
\text { - Management of solid and hazardous waste } \\
\text { and recycling systems }\end{array}$ & 1.762 \\
\hline 850162 & $\begin{array}{l}\text { - AC generators (alternator), of an output } \\
\text { exceeding } 75 \mathrm{kVA} \text { but not exceeding } \\
375 \mathrm{kVA}\end{array}$ & Renewable energy & 1.729 \\
\hline 291421 & $\begin{array}{l}\text { - Cyclanic, cyclenic or cycloterpenic ketones } \\
\text { without other oxygen function: camphor }\end{array}$ & $\begin{array}{l}\text { Environmental technologies: } \\
\text { - Gas flaring emission reduction } \\
\text { - Efficient consumption of energy technologies } \\
\text { Carbon capture and storage }\end{array}$ & 1.702 \\
\hline 841340 & - Concrete pumps & $\begin{array}{l}\text { Environmental technologies: } \\
\text { - Efficient consumption of energy technologies } \\
\text { Carbon capture and storage }\end{array}$ & 1.666 \\
\hline 730459 & $\begin{array}{l}\text { - Other, of circular cross-section, of other } \\
\text { alloy steel: Other }\end{array}$ & $\begin{array}{l}\text { Waste management and water treatment: } \\
\text { - Waste water management and potable water treatment }\end{array}$ & 1.516 \\
\hline 841382 & - Liquid elevators & $\begin{array}{l}\text { Environmental technologies: } \\
\text { - Efficient consumption of energy technologies } \\
\text { Carbon capture and storage }\end{array}$ & 1.483 \\
\hline 846291 & - Other: Hydraulic presses & $\begin{array}{l}\text { Waste management and water treatment: } \\
\text { - Management of solid and hazardous waste } \\
\text { and recycling systems }\end{array}$ & 1.345 \\
\hline 392010 & - Of polymers of ethylene & $\begin{array}{l}\text { Waste management and water treatment: } \\
\text { - Management of solid and hazardous waste } \\
\text { and recycling systems }\end{array}$ & 0.681 \\
\hline 530310 & $\begin{array}{l}\text { - Jute and other textile bast fibres, raw } \\
\text { or retted }\end{array}$ & $\begin{array}{l}\text { Others: } \\
\text { - Environmentally preferable products based on end-use } \\
\text { or disposal characteristics }\end{array}$ & 0.473 \\
\hline 732690 & - Other & $\begin{array}{l}\text { Waste management and water treatment: } \\
\text { - Waste water management and potable water treatment }\end{array}$ & 0.442 \\
\hline 850239 & - Other generating sets: other & Renewable energy & 0.331 \\
\hline 847432 & $\begin{array}{l}\text { - Mixing or kneading machines: machines } \\
\text { for mixing mineral substances } \\
\text { with bitumen }\end{array}$ & $\begin{array}{l}\text { Environmental technologies: } \\
\text { - Efficient consumption of energy technologies } \\
\text { Carbon capture and storage }\end{array}$ & 0.240 \\
\hline 731100 & $\begin{array}{l}\text { - Containers for compressed or liquefied gas, } \\
\text { of iron or steel }\end{array}$ & $\begin{array}{l}\text { Environmental technologies: } \\
\text { - Efficient consumption of energy technologies } \\
\text { Carbon capture and storage }\end{array}$ & 0.120 \\
\hline 841319 & $\begin{array}{l}\text { - Other pumps fitted or designed to be fitted } \\
\text { with a measuring device }\end{array}$ & $\begin{array}{l}\text { Environmental technologies: } \\
\text { - Efficient consumption of energy technologies } \\
\text { Carbon capture and storage }\end{array}$ & 0.058 \\
\hline 560811 & $\begin{array}{l}\text { - Of man-made textile materials: made-up } \\
\text { fishing nets }\end{array}$ & $\begin{array}{l}\text { Others: } \\
\text { - Natural resources protection }\end{array}$ & 0.016 \\
\hline
\end{tabular}

Source: prepared by the author.

HS: Harmonized Commodity Description and Coding System. 
On the basis of this analysis, Barbados has a comparative advantage in just $6 \%$ of the green goods included in the wTo draft universe of environmental goods. Given the island's size, it is unlikely to be a major producer of a diverse set of goods. Nevertheless, the limited extent to which the island is exploiting opportunities in relation to the export of green goods suggests that there remains significant room for growth. This finding is further substantiated by the recent trends in the export of green goods. To assess the extent to which the island has been exploiting these advantages, figure 6 plots the value of green goods exports for Barbados in the period 2007-2009. The figures show that green goods exports still represent just a small share of overall merchandise exports from the island: between $3 \%$ and $4 \%$. In addition, the contribution of green goods exports to total merchandise exports has not changed appreciably. To fully leverage the global demand for green goods, export promotion in these areas will be key over the coming years.

The list in table 3 was limited to green goods, however, since services account for the majority of goods and services exports from Barbados, the island is likely to have comparative advantages in that area as well. Using the questions in section III, each of the categories in the database was assessed and the final results are provided in figure 7.

The results point to potential opportunities in the following areas (figure 7):

- Environmental education (curriculum for green jobs)

- Environmental conservation organizations

- Air, water and waste programme administration

- Waste management services

- Remediation services (waste management)

- Tour operators (green tours)

- Landscaping services (energy efficient landscaping services)

- Advertising and public relations agencies

- Architectural services (LEED-specific architecture services)

- Engineering services (engineering services for renewable energy projects)

- Testing laboratories (environmental testing services)

- Graphic design services (graphic design services for environmental awareness products)

- Contractors (LEED-certified buildings)

- Residential remodelers (weatherization)

- Commercial building construction (LEED-certified buildings)

FIGURE 6

Barbados: value of green goods exports

(Millions of dollars and percentages of total exports)

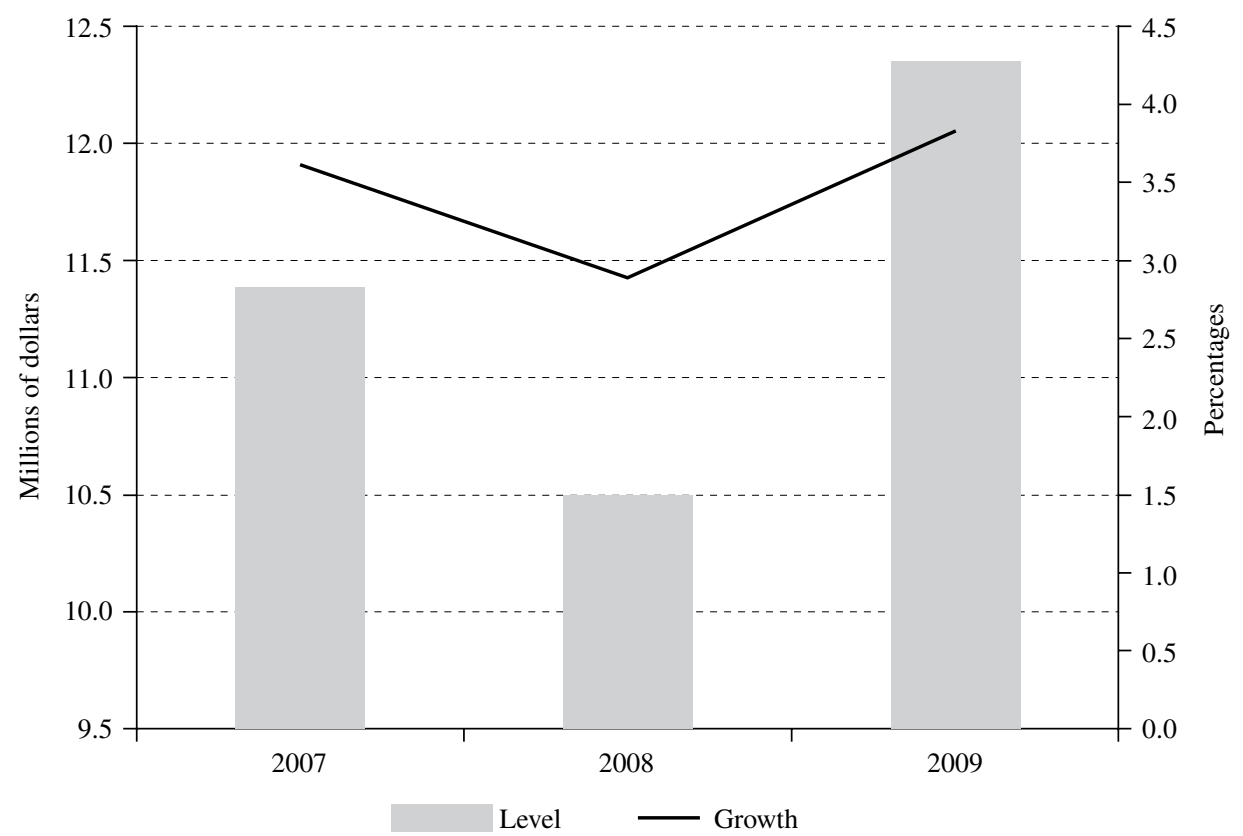

Source: United Nations Commodity Trade Statistics Database (COMTRADE). 


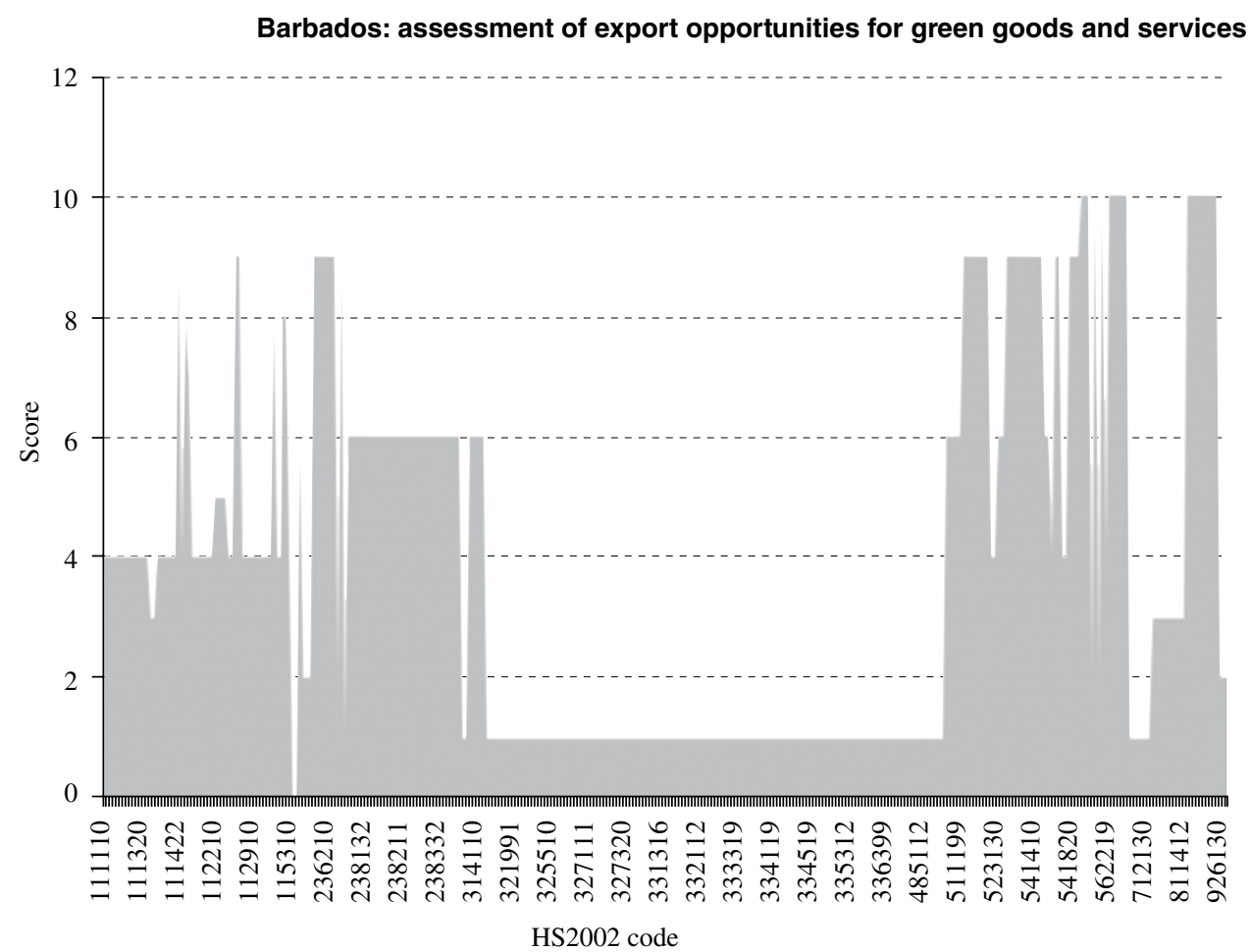

Source: prepared by the author.

HS: Harmonized Commodity Description and Coding System.

Barbados already has a large workforce of trained individuals in the service industry, however, their skills must be enhanced to take advantage of available opportunities. Figure 8 shows the breakdown of employment by occupation and sex at the end of 2011: of an employed population of 127,800 , about $59 \%$ can be classified as service workers, with a large number of those individuals engaged in higher level service professions (for example, technicians and associated occupations).

At present, the Samuel Jackman Prescod Polytechnic provides diploma-level training in mechanical engineering, electrical engineering, construction and architectural studies, among other subjects, while undergraduate and graduate qualifications are available from the University of the West Indies at the campuses in Mona, Jamaica, and Saint Augustine, Trinidad and Tobago. Qualified Barbadian students are eligible to enter the University of the West Indies to pursue studies with full government sponsorship.

Barbados will, however, need to address some training gaps if it is to fully leverage the potential benefits of exporting green services. For example, there is currently no local or regional council to allow skilled service professionals to pursue LEED certifications for their projects; and despite the incentives in place enabling companies and individuals to write off part of the cost of ISO certification, the upfront costs for many small companies can still be prohibitive. 
FIGURE 8

Barbados: employment by occupation and sex

(Thousands of persons)

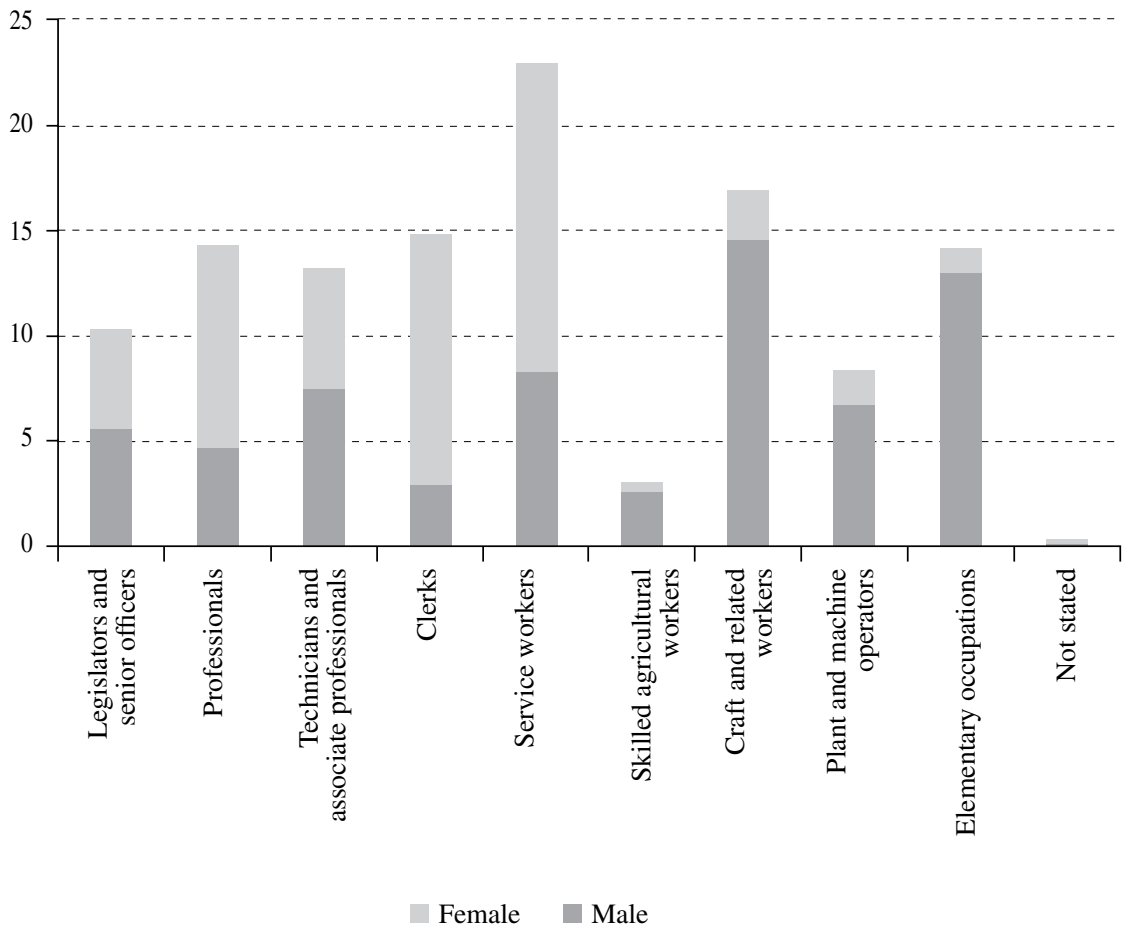

Source: Barbados Statistical Service.

\section{Conclusions and recommendations}

Barbados has adopted ambitious targets in relation to pursuing a green economy. These targets are largely based on the recognition that the island faces significant resource constraints and a vulnerability to price shocks from imported resources (Moore and others, 2012). This paper assesses the potential green export opportunities for the island, analysing both green goods and green services. Using disaggregated trade data at the sixdigit level (HS2002 system of classification), the study calculates indices of revealed comparative advantage in order to identify areas that the island should consider targeting for support. Given the importance of services to the Barbadian economy, opportunities in green services are also examined.
The results of the study suggest that Barbados has a revealed comparative advantage in about 16 green export areas. The total value of these exports, however, is still quite small (less than $4 \%$ of total exports) and has grown at the same rate as total exports in recent years. In relation to services, the number of potential business areas that could leverage the skills and resources of the island was larger. Some institutional support would be needed, however, to help professionals achieve international certification. It should also be noted that developing economies may be able to introduce new goods or services exports, but sustaining that trade is more difficult, with many firms struggling to maintain their market share. These firms need to focus on research 
and development in order to keep their market share and enhance efficiency.

While green goods and services might help to diversify the island's export base, many of these goods and services can build on existing industries. For example, green tours can use existing tourism infrastructure and help the island to enhance the earnings from that industry, while providing a more fulfilling experience for visitors. Barbados has a long history in the manufacture of solar technologies (Moore and others, 2012) and, with sufficient investment, these companies could penetrate a larger number of markets around the world. These are but a few examples, yet they illustrate the potential advantages that can be gleaned from building on the country's knowledge and experience. There would also be potential advantages to pursuing a regional capacitybuilding strategy on the export of green goods and services. For example, rather than setting up individual certification institutes on each island, a regional initiative could be pursued in this respect.

\section{Bibliography}

Balassa, B. (1989), Comparative Advantage, Trade Policy and Economic Development, New York, Harvester Wheatsheaf. (1986), "Comparative advantage in manufactured goods: a reappraisal", Review of Economics and Statistics, vol. 68, No. 2, Cambridge, Massachusetts, The MIT Press.

Bureau of Labor Statistics (2012), "Green Goods and Services", United States Department of Labor [online] http://www.bls. gov/ggs/ggsoverview.htm.

Ernst and Young (2008), Comparative Advantage and Green Business, London, Ernst and Young.

Huberty, M. and G. Zachmann (2011), Green Exports and the Global Product Space: Prospects for EU Industrial Policy, Brussels, Bruegel.

Lall, S. (2001), "Competitiveness indices and developing countries: an economic evaluation of the global competitiveness report", World Development, vol. 29, No. 9, Amsterdam, Elsevier.

Moore, W. and others (2012), Green Economy Scoping Study Sythesis Report. Barbados, Bridgetown, Government of Barbados/United Nations Environment Programme/University of the West Indies. oECD/Eurostat (Organisation for Economic Cooperation and Development/Statistical Office of the European Communities)
(1999), The Environmental Goods and Services Industry: Manual for Data Collection and Analysis, Paris, OECD Publishing.

Porter, M. (1998), Competitive Strategy: Techniques for Analyzing Industries and Competitors, New York, The Free Press.

Sinclair-Desgagné, B. (2008), "The environmental goods and services industry", International Review of Environmental and Resource Economics, vol. 2.

Vollrath, T. (1991), "A theoretical evaluation of alternative trade intensity measures of revealed comparative advantage", Review of World Economics, vol. 127, No. 2, Springer.

World Bank (2010), "Lessons from the Implementation of Republic of Korea's Green Stimulus", INFRA Update [online] http://siteresources. worldbank.org/INTSDNET/Resources/5944695-1247775731647/ INFRA_Korea_Newsletter.pdf.

World Economic Forum (2011), The Global Competitiveness Report 2011-2012, Geneva.

wTo (World Trade Organization) (2011), Report by the Chairman, Ambassador Manuel A.J. Teehankee, to the Trade Negotiations Committee, Geneva, Committee on Trade and Environment. 